\title{
THE COMPARISON BETWEEN SQ5R AND FIX-UP STRATEGY IN READING COMPREHENSION FOR EFL SECONDARY LEVEL LEARNERS
}

\author{
${ }^{1,2}$ Delfia Herwanis, ${ }^{1}$ Rahmanita Zakaria, ${ }^{1}$ Ari Renaldi, \& ${ }^{1}$ Irna Sari \\ ${ }^{1}$ Education Faculty, Islamic State Institute of Takengon, Indonesia \\ ${ }^{2}$ Corresponding Author Email: delfiaherwanis3@gmail.com
}

\begin{tabular}{|c|c|}
\hline Article Info & Abstract \\
\hline $\begin{array}{l}\text { Article History } \\
\text { Received: June } 2021 \\
\text { Revised: July } 2021 \\
\text { Published: July } 2021\end{array}$ & $\begin{array}{l}\text { This study investigates the Survey, Question, Read, Recite, Record, Reflect and } \\
\text { Review (SQ5R) method and Fix-Up strategy to increase students' reading } \\
\text { comprehension of descriptive texts at Tenth grade of MAN } 1 \text { Takengon. The } \\
\text { purpose of this research is to find out the comparison of strategies between }\end{array}$ \\
\hline $\begin{array}{l}\text { Keywords } \\
\text { Writing instructions; } \\
\text { ELT learning; } \\
\text { Communicative learning; }\end{array}$ & $\begin{array}{l}\text { Survey, Question, Read, Recite, Record, Reflect and Review and Fix-Up strategy. } \\
\text { This study used quantitative research using experimental design. The sample of } \\
\text { this study consisted of X-A and X-B classes. The X-A Science class was treated as } \\
\text { the experimental class, and the X-B class was designed as the control class. Both } \\
\text { classes consist of } 20 \text { students. The data of this study were attained using } \\
\text { observation and reading tests. The results showed that the SQ5R strategy was } \\
\text { effective for EFL secondary level learners to facilitate students to attain reading } \\
\text { comprehension at the tenth grade of MAN } 1 \text { Takengon. This study can be } \\
\text { concluded that the SQ5R strategy was more effective than the Fix-Up strategy in } \\
\text { teaching reading comprehension classes. }\end{array}$ \\
\hline
\end{tabular}

How to cite: Herwanis, Zakaria, R., D., Renaldi, A., \& Sari, I. (2021). The comparison between SQ5R and fixup strategy in reading comprehension for EFL secondary level learners, JOLLT Journal of Languages and Language Teaching, 9(3) DOI: https://doi.org/10.33394/jollt.v\%vi\%i.3845

\section{INTRODUCTION}

Reading activities in the teaching of English as a foreign language class are to enhance students' skills, so they are able to understand and access English pieces of literature in the target language (Chen, 2018; Albiladi, 2018). English teachers have been exposing various reading materials and activities to develop students' reading skills. Specifically, they have been applying various instructional reading strategies to activate students' linguistic competence (Par, 2018; Lee \& Chen, 2019; Hanifah \& Afidah, 2018). In this study, the SQ5Q and Fix strategies are applied to help students activate their reading skills with various reading activities. Based on the researcher's observation in MAN 1 Takengon, it was found that almost all students have some problems in reading comprehension ability. The students have difficulties finding the main idea or information in the text. Sometimes, they got trouble expressing the words and stating the vital thing in the text. When the teacher asked some questions about the text, they did not know the text. The students were lack of vocabulary. They did not understand the meaning of the text if they did not open their dictionary. The students' motivation was shallow in learning English.

English lesson was seeing as tricky. They were not interested in learning English because they usually used Indonesian and Gayonese languages daily. The last, the teaching strategy was not suitable for the condition of students. It seems that the class was boring and not alive when reading the course. The researcher applies two strategies to give the solution for this problem. The survey, Question, Read, Recite, Record, Reflect, and Review (SQ5R) and Fix-Up Strategy. Other researchers at other schools have implemented both strategies. 
Both strategies show the same results in improving students' reading comprehension skills. In this study, the researcher compared the two strategies to apply these two strategies to MAN 1 students and, at the same time, found which strategy was more effective to use in understanding descriptive text for MAN 1 Takengon students.

Reading is a critical skill for English students to develop because it allows them to expand their knowledge, vocabulary, and information. Through reading, one can gain a thorough understanding of the text. It could be because many students lack the basic knowledge necessary to comprehend a word, such as how a word combines with other words. It's difficult to glean information from the passage and even more challenging to conclude it. All these issues will affect the students' ability to comprehend the passage and their reading achievement. As a result, those students require strategies or techniques to overcome the obstacle. Reading also provides access to information because it can provide the reader with valuable knowledge. We must learn to read.

According to Williams and Burden (1997), reading is the process of comprehending a written text, which entails extracting as much information as possible from it. It means that the reader should manage each section of the text, as it is simple to comprehend the information contained within, and reading provides the reader with additional knowledge as they can learn and construct the text's meaning. Additionally, Snow defines reading comprehension as the process of simultaneously extracting and making meaning from written language through interaction and involvement. One could argue that reading is fundamentally an active process.

According to Harmer (2001); Kirby (2007); Moore et al. (2016), and Moore (2014), reading comprehension is a receptive skill, and receptive skill refers to the processes by which individuals gather meaning from the discourse or text they have read. Reading comprehension can be defined as a skill in which the reader does more than reading the text. It is a method of grasping the writer's concept and gleaning information from the text; it is about pronouncing or loud reading and comprehending the text and gleaning knowledge and writer massage from the text (Miqawati \& Sultyo, 2014).

Reading and comprehension are inextricably linked because reading results in incomprehension. Without reading comprehension, there is no communication, exceptionally written communication. Based on Richards \& Schmidt (2010), reading comprehension is how the meaning of a written text is comprehended. The purpose of reading and the nature of the text dictates the specific knowledge, skills, and strategies that the reader must employ to understand (Indahwati, 2020). Thus, reading comprehension encompasses a great deal more than decoding. Reading comprehension occurs when the reader is aware of the appropriate skills and strategies for the type of text and understands how to apply them to accomplish the reading objective.

To enhance the quality of teaching and learning, the teacher should employ an effective teaching method because it is in line with Malia and Yasin (2015) who informed that reading activities that are started from preview, question, and read strategies is able to help students enhance their background knowledge during the reading processes. As a result, the researcher wishes to use two reading techniques. The SQ5R process and fix-up strategy. The SQ5R is a development of the SQ3R and SQ4R methods. SQ5R (Survey, Question, Read, Recite, Record, Reflect, and Review) is a reading technique that is used to help students improve their ability to comprehend a text (Sangcharoon, 2010). And the fix-up strategy is a strategy that can help the students understand the message of the text when they get stuck with certain words or certain sentences. This means that SQ5R and fix- Up strategy is the reading methods designed to assist students in processing and improving their retention of written information, as well as a comprehension strategy that encourages students to become active participants in the reading process, focusing their attention on the text, attracting their motivation, 
developing a long-term memory for comprehending the text, and increasing their reading achievement.

\section{SQ5R Method and Fix-Up Strategy}

SQ5R is a reading method for academic purposes that consists of seven stages: survey, question, read, recite, record, reflect, and review. Walter Pauk developed its (Walter Pauk, 2013). The SQ5R is an adaptation of Robinson's original SQ3R technique. It consists of five steps: survey, question, read, recite, and review. When refined into a smooth and efficient method, students read more quickly, picking out key points and retaining them in their memory (Francis. P. Robinson, 1970). The SQ3R has been enhanced to become the SQ4R by adding a "record or write" step. Students complete this step by writing a summary of the text. Following that, Pauk expanded on Robinson's SQ4R technique by including a reflection step, creating Pauk's SQ5R, including Survey, Question, Read, Recite, Record, Reflect, and Review. It means that the SQ5R method evolved from the SQ3R and SQ4R processes to address the shortcomings of the previous methods. And then, this method was created to assist students in efficiently learning, particularly in reading text, and students expected that learning to read would be simple. Here are a few additional points (Bepko Learning Center, 2012); (Tonomchit, 2009); (Meaningful Learning from Text through Purposeful Reading: SQ5R, n.d.). The central idea is that the reader wishes to layer the information. Adding layers strengthens concepts far more than removing them and reading straight through to complete the reading. What good is information if the reader does not comprehend or retain it? The sequence of the first three steps (S-Q-R) is critical. They may appear banal, but each stage has a purpose. Conduct the survey expeditiously. Scan and turn the pages at a rate of approximately 4-5 per minute.

According to the preceding explanation, the SQ5R method can be defined as a reading method for study purposes that consists of seven stages: survey, question, read, recite, reflect, record, and review. Demonstrate what the acronym S-Q-R-R-R-R means: Survey, Question, Read, Recite, Record, Reflect, and Review. It is a component of students' ability to learn more effectively from a text. It means that students will have little difficulty extracting information from the text (Basar \& Gurbuz, 2017).

\section{Fix-Up Strategy}

While it is not unusual for a reader to monitor the meaning of the reading material during the reading process, there are times when something makes no sense. Typically, when confronted with this problem, the reader seeks out a technique for resolving it. One appropriate method for resolving this issue is to employ the Fix-it or Fix-up strategy. When students become stuck on certain words or sentences, the fix-up strategy can assist them in comprehending the text's message.

A reader can benefit from a fix-up strategy, and it applies to all readers, including students. When a reader has difficulty reading a text, the fix-up strategy assists them. As Janette states, a fix-up strategy is one that a reader uses to help them escape when the text becomes confusing. According to Klingner., Vaughn., \& Bordman (2015), readers employ the fix-up strategy when they cannot comprehend what they hear or read.

Judi Moreillon (2007) asserts that the fix-up strategy provides readers with processes for regaining meaning, such as rereading, reading ahead, or figuring out unknown words. Then, one of the strategies that can assist students in comprehending a text is the fix-up strategy. According to Trehearne (2004), a fix-up strategy is used when readers experience a loss of concentration or a break in concentration.

The fix-up strategy is what you use to assist yourself in becoming unstuck while reading perplexing texts (Cris Tovani, 2000). Additionally, Moreillon stated in his study that fix-up options are tools that readers can use to navigate their way home and make sense of what they 
read. In a nutshell, the fix-up strategy is a reading comprehension strategy used to assist readers in becoming unstuck while reading text and making sense of what they read.

Additionally, Gerald (2009) stated that the term "fix-up strategy" is frequently used to refer to a technique in which readers search backward and occasionally forward in a text in order to resolve a meaning blockage encountered while reading. To use it effectively, readers must first understand that it is critical to monitor meaning as they read and that good readers will pause when they encounter a problem. In short, a reader should recognize that he or she does not understand the meaning of a particular word in the text and then attempt to determine the meaning by rereading, utilizing prior knowledge, thinking, and reflecting on resolving the issue. After identifying the cause, the reader can visualize, retell, and make observations about what they have already gleaned from the text.

\section{RESEARCH METHOD}

This study employs a quantitative methodology. Quantitative research is a method of investigation that is based on the positivism philosophy. It is a process of data collection that utilizes statistical formulas and many specific data. It means that the quantitative approach is the method by which the researcher interprets and collects data from the research using statistics or numbers. Cresswell (2009) stated that a quantitative approach is one in which the investigator primarily relies on postpositivist claims for knowledge development (i.e., cause and effect thinking, reduction to specific variables and hypotheses and questions, use of measurement and observation, and testing theories), employs inquiry strategies such as experiments and surveys, and collects data on predetermined instruments that yield statistics. As stated previously, the quantitative approach is one in which the researcher develops knowledge about the variable and hypothesis by statistical data, experiments, and test to collect data.

\section{Research Design}

The objective of quantitative research is to ascertain the effect of treatment on two classes of experimental and groups. It means that a quantitative approach was applied in this study to the entire sample divided into two classes as an experimental class. However, the treatment is used to both of classes. The sample used in this research was X Scince 2 class as the experimental class 1 and the experimental class $2 \mathrm{X}$. Both classes consist of 20 students. Techniques of data collection there are observation and test.

\section{Population and Sample}

According to Ary, D (2002) a population is defined as all individuals who belong to a well-defined group of people, events, or objects. The population size has a significant impact on the population's trajectory. If it is large, the researcher will almost certainly encounter difficulties conducting the research, such as a lack of funds, energy, and time. To circumvent these difficulties, the researcher may collect a sample. The population of this study is comprised of all tenth-grade students in MAN 1 Takengon, a total of 221 students. The sampling technique used in this study is random sampling. The researcher took a sample order to teach reading using the SQ5R method to 20 students and to teach reading using fix-up strategy to 20 students in MAN 1 Takengon's tenth grade.

\section{Instruments}

The instrument in this study applied observation sheet and test sheet. The purpose of observation was to observe the students' physical condition and their habits during the learning process. The observation focused on several factors, including students' reading ability, their problems, and their motivation. The reading comprehension test used in this study was administered by providing a reading text, instructing students to read it, and then posing questions based on the information found in the text. 


\section{Data Analysis}

The data analysis of this study applied descriptive statistics and inferential statistics. The purpose of descriptive statistics is to provide information about the research subject using data from the group that conducted the research. Meanwhile, inferential statistics is a technique of statistics that involves analyzing a sample of data and determining the effect on populations. After collecting data, the researcher will calculate the students' scores and compare the scores of the experimental using fix-up strategy and the experimental class using SQ5R method used Independent Sample T-Test SPSS.

\section{RESEARCH FINDINGS AND DISCUSSION Research Findings}

This study investigates the comparison between the SQ5R method and Fix-Up Strategy to increase students' reading comprehension of descriptive texts. The English teacher was applied the SQ5R method and Fix up strategy in teaching reading skills. The students' reading achievement was different results. The mean score of students' reading skills in the SQ5R class was 82.75, while the mean score of it in the fix-up strategy was 76.4. The mean score of students' reading skills and the score of t-test can be presented in Table 1 and 2 as follows.

Table 1

The score of T-Test

\begin{tabular}{llllrr}
\hline & CLASS & N & Mean & Std. Deviation & Std. Error Mean \\
\hline \multirow{3}{*}{ The result of test } & SQ5R & 20 & 82.7500 & 6.43898 & 1.43980 \\
\cline { 2 - 6 } & FIX-UP & 20 & 76.4000 & 7.84320 & 1.75379 \\
\hline
\end{tabular}

Table 2

Independent Samples Test

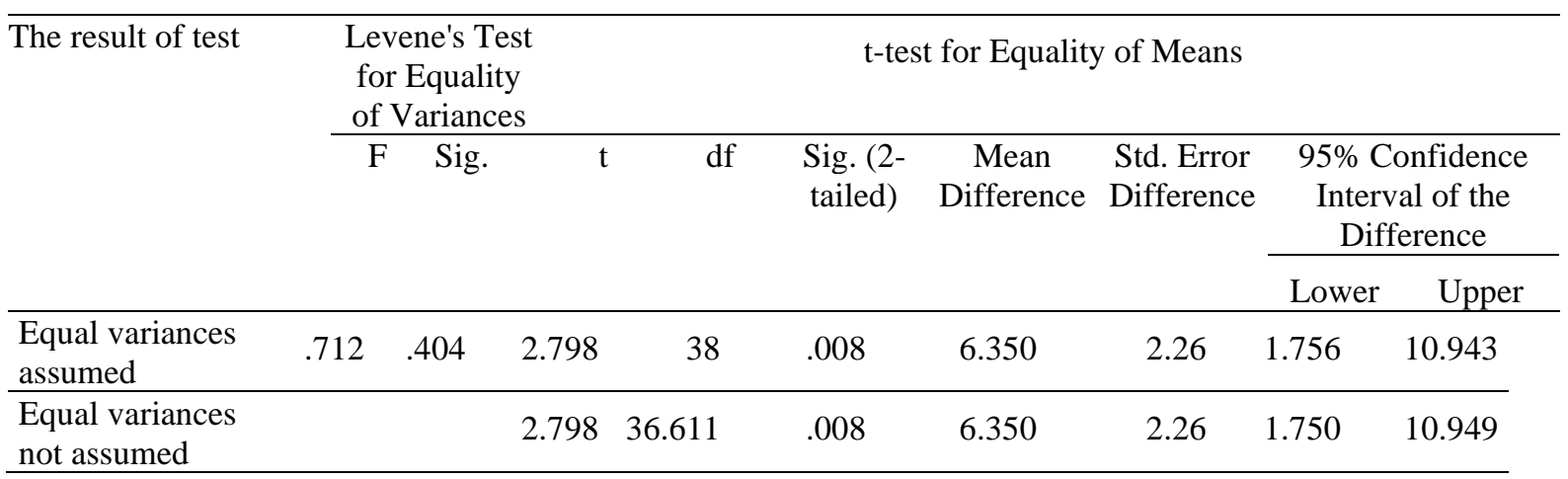

From table 3 of the independent samples test above can conclude, there is the significance (2-tailed) 0,008 , it means if the significance (2-tailed) $<0,05$, there is a significant difference result between SQ5R class and fix-up Strategy Class. The SQ5R method was more effective in improving students' reading comprehension ability than the fixup strategy. It is the primary reason for the study's findings that SQ5R is more effective than the fix-up strategy at improving students' reading comprehension skills.

\section{Discussion}

This study aims to investigate the comparison between the SQ5R strategy and Fix-up strategy to enhance students' reading skills. According to Malia and Yasin (2015), reading comprehension is the active process of deriving meaning from a text; it entails drawing on 
prior knowledge, comprehending vocabulary and concepts, inferring, and connecting key ideas. That is, reading comprehension is the reader's activity of deriving meaning from text (Aziz et al., 2019; Haryati \& Hidayati, 2017). As a result, the researcher wishes to advocate for the result in reading ability acquisition. To assist students in comprehending the text, the researcher introduces a reading comprehension technique. That is the method known as the Survey, Question, Read, Recite, Reflect, Record, and Review (SQ5R).

The SQ5R method is one method for teaching English, particularly reading. Based on the teaching practice, English teacher feel easy to guide students in accomplisong their reading activities. It is in accordance with Indahwati (2020) who state the question, read, and recite activities can help students administer their skills to read any text. In addition, this method can help students become more adept at reading English and answering questions as students must complete all of the steps in this method (Schmitterer \& Schroeder, 2019). Additionally, students read the text more carefully. After researching reading using and learning the SQ5R method, the researcher observes some improvements in the students' reading ability.

Three stages comprise the outcome of teacher observation. The first step is to prepare. The teacher rarely begins preparing the lesson plan during this stage. Following that, delivering material, the issue is that the teacher did not communicate the purpose of teaching before the lesson began. The teacher rarely motivated the students. Teaching was incapable of clearly answering students' questions or of satisfying them. The final stage is implementing a method or strategy for teaching-learning, in which the teacher employs a standardized strategy for delivering material. The teacher then gave the standard illustration and example without modification.

The Fix-up strategy is a strategy that can help the students' understand the message of the text when they get stuck with certain words or certain sentences. This strategy can increase students' reading comprehension ability, too, but lower than using the SQ5R method. Meaning the students' score test using the SQ5R method higher than teaching reading comprehension using Fix-Up Strategy.

\section{CONCLUSION}

The test data results for the SQ5R class and the Fix-Up Strategy class indicate that both methods are capable of increasing students' reading comprehension ability, but the results of teaching reading using the SQ5R were significant compared to the results for students in the fix-up strategy class.

\section{ACKNOWLEDGEMENT}

On this unique occasion, the writer wishes to express her heartfelt appreciation: 1) She appreciates her adoring husband for his eternal love, prayers, and support, and the rest of her incredible family for their prayers and support. 2) She expresses gratitude to Dr. Zulkarnain, M.Ag, for his leadership of the State Institute of Islamic Studies Takengon and his support in writing this study. 3) She would like to express his heartfelt appreciation to the reviewer and editor of this journal for their invaluable time spent encouraging, guiding, suggesting, and advising her until this study is finished and published. 


\section{REFERENCES}

Albiladi, W. S. (2018). Exploring the Use of Written Authentic Materials in ESL Reading Classes: Benefits and Challenges. English Language Teaching, 12(1), 67. https://doi.org/10.5539/elt.v12n1p67

Ary, D. (2002). Introduction to Research in Education. Wadsworth group a division of Thompson learning inc.

Aziz, Z. A., Nasir, C., \& Ramazani, R. (2019). Applying Metacognitive Strategies in Comprehending English Reading Texts. Celt: A Journal of Culture, English Language Teaching \& Literature, 19(1), 138. https://doi.org/10.24167/celt.v19i1.1863

Basar, M., \& Gurbuz, M. (2017). Effect of the SQ4R Technique on the Reading Comprehension of. International Journal of Instruction, 10(2), 131-144.

Bepko Learning Center. (2012). SQ5R Reading System: The Steps of SQ5R. Bepko Learning Center, 1-3. http://blc.uc.iupui.edu/Portals/BLC/Study Skills/Fall 15 Handout Updates/SQ5R Reading Method.pdf

Chen, I. C. (2018). Incorporating task-based learning in an extensive reading programme. ELT Journal, 72(4), 404-414. https://doi.org/10.1093/elt/ccy008

Creswell, J. W. (2009). Research design: Qualitative, quantitative, and mixed methods approaches (3rd ed., Vol. 35, Issue 2). CA: Sage. https://doi.org/10.4324/9780203093917

Cris Tovani. (2000). I read it, but I don't get it: Comprehension strategies for adolescent readers. Stenhouse Publisher.

Francis. P. Robinson. (1970). Effective Study. Harper\& Row.

Gerald, G. D. (2009). Explaining Reading. Guillford Press.

Hanifah, H., \& Afidah, N. (2018). Developing textbook by using reading strategic based instruction method for shariah economy department. JEES (Journal of English Educators Society), 3(2), 155. https://doi.org/10.21070/jees.v3i2.1552

Harmer, J. (2001). The Practice of English Language Teaching. In ELT Journal (Third Edit, Vol. 57, Issue 4). Longman. https://doi.org/10.1093/elt/57.4.401

Haryati, S., \& Hidayati, D. N. (2017). Hoax News: Promoting the Students' Critical Thinking in Critical Reading Class. Register Journal, 10(2), 122. https://doi.org/10.18326/rgt.v10i2.122-139

Indahwati, E. E. (2020). Autonomous Online Reading Using PQRST to Enhance The Students Reading Skill In Recount Text. EDUCAFL: Journal of Education of English as Foreign Language, 3(1), 17-23.

Judi Moreillon. (2007). Collaborative strategies for teaching reading comprehension. American Library Association.

Kirby, J. R. (2007). Reading comprehension: its nature and development. Encyclopedia of Language and Literacy Development, August, 0-8.

Klingner., Vaughn., \& B. (2015). No Title (Second Edi). Guillford Press.

Lee, K., \& Chen, X. (2019). An emergent interaction between reading fluency and vocabulary in the prediction of reading comprehension among French immersion elementary students. Reading and Writing, 32(7), 1657-1679. https://doi.org/10.1007/s11145-0189920-z

Malia, N., \& Yasin, A. (2015). Using PQRST strategy to improve students' reading comprehension of hortatory exposition texts at grade XI IPS of MA Diniyah Puteri, Pekanbaru. English Language Teaching (ELT), 3(1).

Miqawati, A. H., \& Sulistyo, G. H. (2014). The PQRST strategy, reading comprehension, and learning styles. Indonesian Journal of Applied Linguistics, 4(1), 123-139.

Moore, A. L. (2014). A Research Review of Cognitive Skills, Strategies and Interventions for ltReading comprehension. 1-22. http://downloads.learningrx.com/reading- 
comprehension-research-paper.pdf

Moore, J. J., McClelland, S. S., Alef, E. C., \& Vogel, E. D. (2016). The Simplicity and Complexity of Reading Comprehension. Internationa Journal of Business and Social Science, 7(6), 20-26. https://ijbssnet.com/journals/Vol_7_No_6_June_2016/3.pdf

Par, L. (2018). The EFL students' critical reading skills across cognitive styles. JEELS, 5(1), 73-96. https://doi.org/https://doi.org/10.30762/jeels.v5i1.570

Richards, J. C., \& Schmidt, R. (2010). Longman language teaching \& Applied Linguistics. lib.gen.rus.ac

Sangcharoon, T. (2010). Reading and Writing Skills Development: The Use of SQ\%R Technique. Thesis, May, 1-29.

Schmitterer, A. M. A., \& Schroeder, S. (2019). Effects of reading and spelling predictors before and after school entry: Evidence from a German longitudinal study. Learning and Instruction, 59(June 2017), 46-53. https://doi.org/10.1016/j.learninstruc.2018.09.005

Sangcgaroon. (2009). Reading and writing skills development the use of PQ5R technique. To

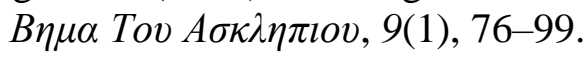

Trehearne, M. (2004). Fix-up Strategies Tips for Parents Strategies : 2004.

Walter Pauk. (2013). How to Study in College. Houghton Mifflin Company Boston.

Williams \& Burden. (1997). Psychology for language teachers. Cambridge University Press. Meaningful Learning from Text through Purposeful Reading : SQ5R. 